\title{
Treatment of Morsicatio Buccarum by Oral Appliance: Case Report
}

\author{
Min Chang, Jiyeon Kim, YounJung Park, Jeong-Seung Kwon, \\ Seong-Taek Kim, Jong-Hoon Choi, Hyung-Joon Ahn
}

Department of Orofacial Pain and Oral Medicine, Dental Hospital of Yonsei University College of Dentistry, Seoul, Korea

\author{
Received August 25, 2021 \\ Revised September 16, 2021 \\ Accepted September 16, 2021 \\ Correspondence to: \\ Hyung-Joon Ahn \\ Department of Orofacial Pain and Oral \\ Medicine, Dental Hospital of Yonsei \\ University College of Dentistry, 50-1 Yonsei- \\ ro, Seodaemun-gu, Seoul 03722, Korea \\ Tel: +82-2-2228-3113 \\ Fax: +82-2-393-5673 \\ E-mail: HJAHN@yuhs.ac \\ https://orcid.org/0000-0001-9669-9781
}

This work was supported by the National Research Foundation of Korea (NRF) grant funded by the Korea government (MSIP) (no. 2016R1A5A2008630).
Morsicatio buccarum is a condition caused by chronic cheek biting. It means frictional hyperkeratosis by repetitive cheek biting, which may be associated with obsessive compulsion. Clinically it presents as rough, shaggy, whitish, often peeling surface. We report a 9-yearold female patient who complained oral ulceration on both buccal mucosa. The initial diagnosis was oral candidiasis because of whitish plaques which were peeled off. Topical antifungal agent was ineffective and the symptom did not disappear. By incisional biopsy, she was diagnosed with morsicatio buccarum. A soft oral appliance was placed in the patient's oral cavity. Although morsicatio buccarum improved significantly when the appliance was used, the oral lesion had a tendency to recur, when the patient stopped using the appliance. In case of recurrence, cognitive behavioral therapy for obsessive-compulsive disorder is needed for the fundamental treatment.

Key Words: Cognitive behavioral therapy; Compulsive behavior; Keratosis; Occlusal splints

\section{INTRODUCTION}

Morsicatio mucosa oris is a common chronic mucosal frictional keratosis [1]. It is a condition caused by habitual chewing of the lips (morsicatio labiorum), tongue (morsicatio linguarum), or buccal mucosa (morsicatio buccarum) [2]. Sewerin divided all age groups into 5-year-old units and investigated the prevalence rate. The condition is estimated to afflict most frequently among persons in the 15-19 age group (1.77\%). The second largest group was in the 20-24 age group (1.20\%). Prevalence is similar in females (57\%) and males (43\%) [3].

It has generally accepted that morsicatio buccarum is a self-inflicted injury caused by habitual behaviors related to mental problems or stress [4]. The damage is as result of psychological conflicts and emotions such as hate, jealousy, exacerbation, aggression, a feeling of inferiority and isolation, a feeling of compassion, and problem of identity [3]. Some patients with excessive anxiety during daytime tend to bite their buccal mucosa unwittingly while sleeping [5]. In addition, Fatima et al. [6] suggested that morsicatio buccarum and depression are also closely related to each other in recent study.

Morsicatio mucosa oris usually affects the buccal mucosa, lateral border of the tongue, or the lower labial mucosa that are easily accessible to, and readily injured by the teeth. It represents poorly demarcated, uneven, shaggy, peeling, white papules, and plaques [1]. Therefore, differential diagnosis with pseudomembranous candidiasis sometimes needs to be performed.

In this paper, we present the case of a 9-year-old female patient who was diagnosed with morsicatio buccarum with clinical findings similar to candidiasis and improved in symptoms receiving an oral appliance treatment. 

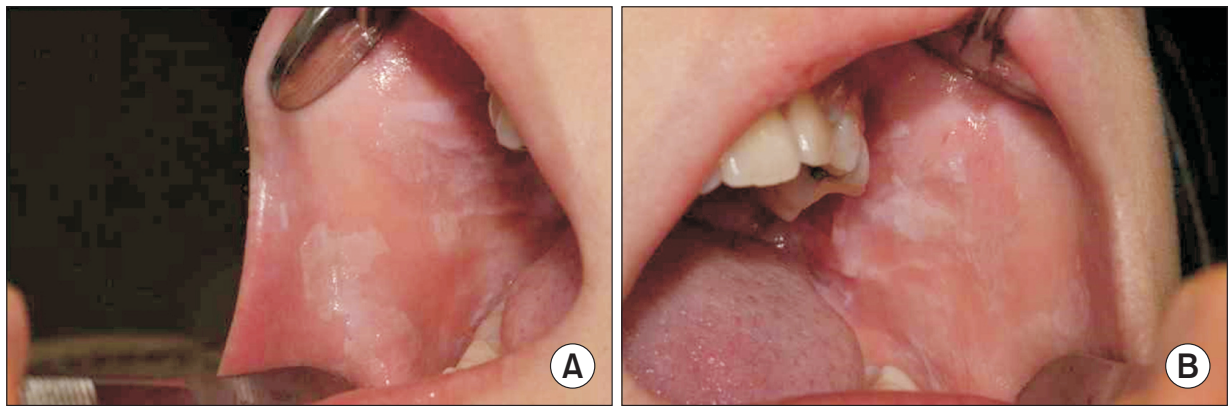

Fig. 1. Clinical photographs showing white plaques on the buccal mucosa. (A) Right side. (B) Left side.

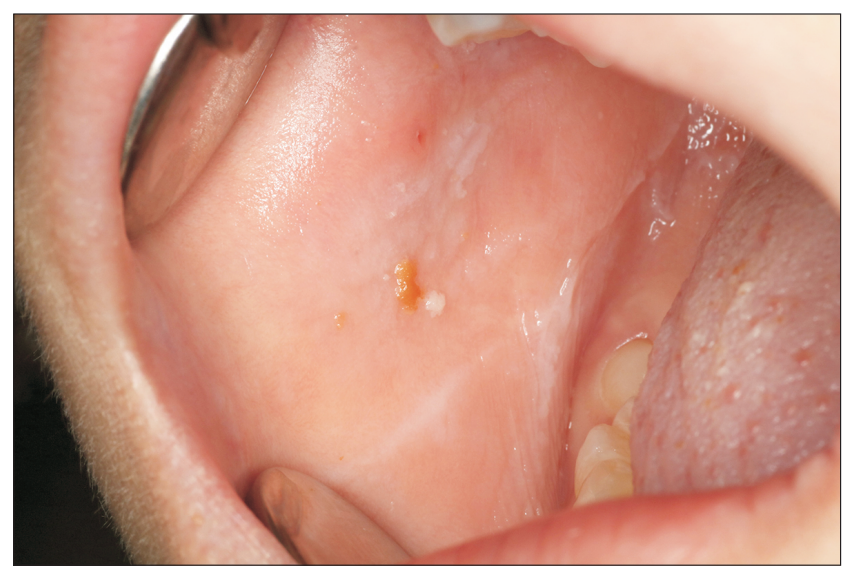

Fig. 2. Clinical photographs showing improved lesion when the patient wore the appliance every day.

\section{CASE REPORT}

A 9-year-old female visited the Department of Orofacial Pain and Oral Medicine in Dental Hospital of Yonsei University College of Dentistry (Seoul, Korea) with a complaint of oral ulceration (IRB no. 2021-0139-001). She was referred from department of pedodontics for assessment of the lesions of oral cavity. Her medical history was unremarkable. The symptoms started about 2 weeks ago. She had spontaneous pain that persisted during the first week, but at the time of her visiting to the hospital she complained of stinging feeling from stimulating foods without spontaneous pain. Clinical examination revealed the patient presented with whitish plaques peeled off on both buccal mucosa with tenderness to palpation (Fig. 1). She said that her mouth was dry and the lesion seemed to be getting wider over time. The initial diagnosis was oral candidiasis. She was treated with antifungal agent, fluconazole dry syrup (Diflucan; Pfizer, Amboise, France) but no appreciable improvement was observed clinically. Therefore, a punch

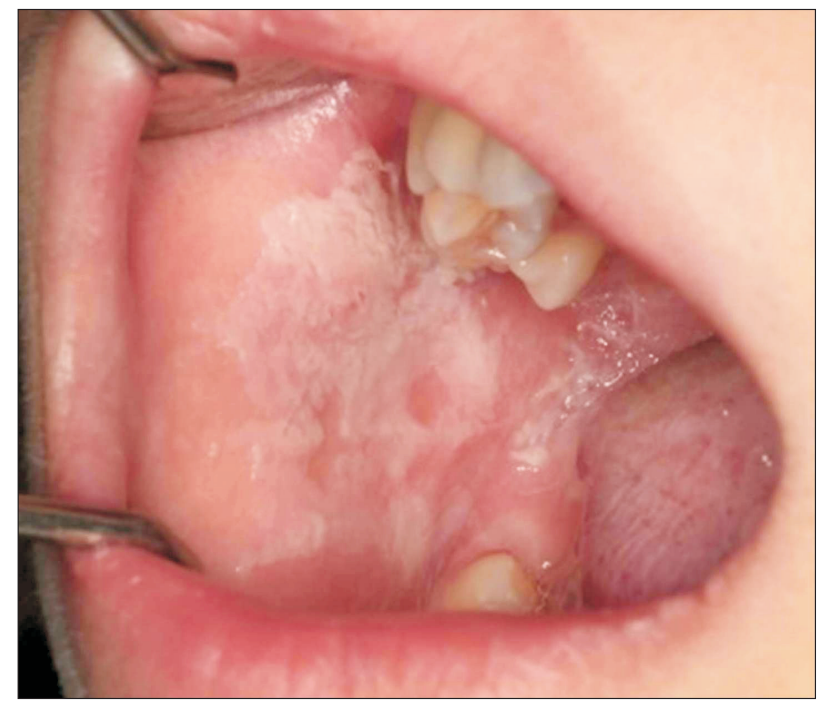

Fig. 3. Clinical photograph showing aggravated lesion when the patient wore the appliance every other day.

biopsy was performed. A diagnosis of morsicatio buccarum was reached based on the histological findings.

The patient recognized that she habitually chewed and bit her buccal mucosa. It was inferred that the lesion was accessible by the teeth. A soft oral appliance was prescribed for the maxillary arch. The patient was instructed to wear the appliance at night. We expected that the soft appliance would prevent her from biting buccal mucosa during the night. Furthermore, the appliance would allow healing time of injured oral tissues. After three weeks, the lesion of the buccal mucosa was significantly improved (Fig. 2).

However, as the patient wore the appliance every other day, the lesion recurred (Fig. 3). In addition to that, after the eruption of the permanent teeth, the appliance did not fit well. When she stopped wearing the appliance, the lesion tended to recur. 


\section{DISCUSSION}

Morsicatio buccarum is the white lesion that is derived from chronic frictional trauma. A considerable number of adolescents suffer from this disease. It was hypothesized that the stress by intense studying in the period of adolescents would be associated with the prevalence [7].

Morsicatio buccarum needs to be differentially diagnosed from other white lesions such as pseudomembranous candidiasis, thermal or chemical burn, allergic reaction by toothpaste or mouthwash, lichen planus, leukoedema, and white sponge nevus [8]. Lesions of morsicatio buccarum are present as a pitted and/or grey-white macerated appearance which are diffuse and roughened on the buccal mucosa. Rubbing makes it possible for some of the fragments of epithelium removed [9]. Therefore, it is likely that clinicians confuse it especially with pseudomembranous candidiasis.

Because morsicatio buccarum is caused by habitual chewing or trauma to teeth, the treatment includes noninvasive therapies such as prostheses or occlusal splints and invasive therapies such as smoothing or extracting teeth [10].

Many kinds of oral appliances or prosthesis have been advocated for interception of lip and cheek biting. Prosthesis with a labial flange was suggested in patient's mouth for neurologic problems or head and neck surgery [11]. Removable oral prosthesis was designed to prevent self mutilation of oral tissues using buccal shields [12]. Intraoral soft appliance was made for targeting the self-injurious habit [13]. Above these appliances, cheek plumper with labial bow, modified pin head clasp, lingual plate, and buccal shield was developed [14]. However, there have not been the researches to compare the effectiveness of these oral appliances.

According to the latest (5th) edition of the Diagnostic and Statistical Manual of Mental Disorders [15], morsicatio buccarum is categorized as a body-focused repetitive disorder as well as subcategory of obsessive-compulsive and related disorders. The examples of body-focused repetitive disorder are cheek biting, hair pulling, skin picking, nail biting, and teeth grinding [16].

There is general consensus that the best treatment for body focused repetitive disorder such as morsicatio buccarum is cognitive behavioral therapy [17]. In order to treat auto-aggressive impulse control disorders, decoupling, a pioneering self-help technique, was developed [18]. The technique is composed of two steps. After the patient recognizes the regular behavioral pattern preceding the habit, he or she is then instructed to perform a movement resembling the initial behavioral sequence of the habit. When it comes to morsicatio buccarum, instead of biting the cheek, the patient is redirected to rub his or her teeth intensely over upper and lower lips or tongue [10].

In our case, the diagnosis of morsicatio buccarum was made based on histological findings. Because clinical feature of morsicatio buccarum could be similar to pseudomembranous candidiasis, past medical history and oral habit should be checked in order to differentiate the two diseases. Although oral appliances could be helpful in treating morsicatio buccarum, they are not apt for the fundamental treatment

In this case, we prescribed the oral appliance during the night, which may protect the oral mucosa from the damage originated from bruxism or nocturnal clenching related with psychological conflicts and emotions. However, we realized that splints should be used during the day in order to maximize the effectiveness of the appliance, considering obsessive behavior usually occurs during the day.

For obsessive-compulsive and related disorders such as trichotillomania and nail biting, behavioral therapy like decoupling was successful in two cases of randomized controlled trials $[19,20]$. There was also a case report that decoupling made it possible for morsicatio buccarum patient to stop the behavior completely [10]. Therefore, cognitive behavioral therapy such as decoupling should be considered for the treatment of morsicatio buccarum.

\section{CONFLICT OF INTEREST}

No potential conflict of interest relevant to this article was reported.

\section{ORCID}

\author{
Min Chang \\ https://orcid.org/0000-0002-3337-9593
}




\author{
Jiyeon Kim \\ https://orcid.org/0000-0002-2150-6882 \\ YounJung Park \\ https://orcid.org/0000-0002-9152-7849 \\ Jeong-Seung Kwon \\ https://orcid.org/0000-0003-4584-7355 \\ Seong-Taek Kim \\ https://orcid.org/0000-0001-9506-5103 \\ Jong-Hoon Choi \\ https://orcid.org/0000-0003-3211-3619 \\ Hyung-Joon Ahn \\ https://orcid.org/0000-0001-9669-9781
}

\section{REFERENCES}

1. Woo SB, Lin D. Morsicatio mucosae oris--a chronic oral frictional keratosis, not a leukoplakia. J Oral Maxillofac Surg 2009;67:140146.

2. Min K, Park C. Morsicatio labiorum/linguarum- three cases report and a review of the literature-. Korean J Pathol 2009;43:174-176.

3. Sewerin I. A clinical and epidemiologic study morsicatio buccarum-labiorum. Scand J Dent Res 1971;79:73-80.

4. Kang HS, Lee HE, Ro YS, Lee CW. Three cases of 'morsicatio labiorum'. Ann Dermatol 2012;24:455-458.

5. Ngoc VTN, Hang LM, Bach HV, Chu DT. On-site treatment of oral ulcers caused by cheek biting: a minimally invasive treatment approach in a pediatric patient. Clin Case Rep 2019;7:426-430.

6. Fatima R, Abid K, Baig NN, Ahsan SB. Association of cheekbiting and depression. J Pak Med Assoc 2019;69:49-52.

7. Amadori F, Bardellini E, Conti G, Majorana A. Oral mucosal lesions in teenagers: a cross-sectional study. Ital J Pediatr 2017;43:50.

8. Tomás Carmona I, Cameselle Tejeiro J, Diz Dios P, Seoane Lestón J, Castro Ferreiro M, Limeres Posse J. Morsicatio linguarum versus oral hairy leukoplakia. Dermatology 2000;201:281-282.

9. Van Wyk CW, Staz J, Farman AG. The chewing lesion of the cheeks and lips: its features and prevalence among a selected group of adolescents. J Dent 1977;5:193-199.

10. Moritz S, Müller K, Schmotz S. Escaping the mouth-trap: recovery from long-term pathological lip/cheek biting (morsicatio buccarum, cavitadaxia) using decoupling. J Obsess Compuls Relat Disord 2020;25:100530.

11. Hatjigiorgis CG, Martin JW. An interim prosthesis to prevent lip and cheek biting. J Prosthet Dent 1988;59:250-252.

12. Romero M, Vicente A, Bravo LA. Prevention of habitual cheek biting: a case report. Spec Care Dentist 2005;25:214-216.

13. Bhatia SK, Goyal A, Kapur A. Habitual biting of oral mucosa: a conservative treatment approach. Contemp Clin Dent 2013;4:386389.

14. Rana V, Srivastava N, Kaushik N, Panthri P. Cheek plumper: an innovative anti-cheek biting appliance. Int J Clin Pediatr Dent 2016;9:146-148.

15. American Psychiatic Association. Diagnostic and statistical manual of mental disorders (DSM-5). 5th ed. Arlington: American Psychiatic Association; 2013.

16. Grant JE, Stein DJ, Woods DW, Keuthen NJ. Trichotillomania, skin picking, and other body-focused repetitive behaviors. Washington, D.C.: American Psychiatric Publishing; 2012.

17. Lochner C, Roos A, Stein DJ. Excoriation (skin-picking) disorder: a systematic review of treatment options. Neuropsychiatr Dis Treat 2017;13:1867-1872.

18. Moritz S, Rufer M. Movement decoupling: a self-help intervention for the treatment of trichotillomania. J Behav Ther Exp Psychiatry 2011;42:74-80.

19. Moritz S, Treszl A, Rufer M. A randomized controlled trial of a novel self-help technique for impulse control disorders: a study on nail-biting. Behav Modif 2011;35:468-485.

20. Weidt S, Klaghofer R, Kuenburg A, et al. Internet-based self-help for trichotillomania: a randomized controlled study comparing decoupling and progressive muscle relaxation. Psychother Psychosom 2015;84:359-367. 